\title{
Cloning, Overexpression and in vitro Antifungal Activity of Zea Mays PR10 Protein
}

\author{
Niloofar Zandvakili, Mohammadreza Zamani*, Mostafa Motallebi, Zahra Moghaddassi Jahromi \\ Department of Plant Molecular Biotechnology, Institute of Agricultural Biotechnology (IAB), NIGEB, Tehran, 14965/161, \\ Iran \\ "Corresponding author: Mohammadreza Zamani, Department of Plant Molecular Biotechnology, Institute of Agricultural Biotechnology (IAB), NIGEB, \\ Tehran, 14965/161, Iran Tel: +98 21 44787301-10, Fax: +98 21 44787399, E-mail: zamani@nigeb.ac.ir
}

Received: 26 Sep. 2015 Revised: 1 Oct. 2016 Accepted: 8 March $2017 \quad$ Published online: 28 May 2017

Background: Plants have various defense mechanisms such as production of antimicrobial peptides, particularly pathogenesis related proteins (PR proteins). PR10 family is an essential member of this group, with antifungal, antibacterial and antiviral activities.

Objective: The goal of this study is to assess the antifungal activity of maize PR10 against some of fungal phytopathogens. Materials and Methods: Zea mays PR10 gene (TN-05-147) was cloned from genomic DNA and cDNA and overexpressed in Escherichia coli. The existence of a 77- bp intron and two exons in PR10 was confirmed by comparing the genomic and cDNA sequences. The PR10 cDNA was cloned in pET26b (+) expression vector and transformed into $E$. coli strain Rosetta DE3 in order to express PR10 recombinant protein. Expression of the recombinant protein was checked by western analysis. Recombinant PR10 appeared as insoluble inclusion bodies and thus solubilized and refolded. PR10 was isolated using NiNTA column. The activity of the refolded protein was confirmed by DNA degradation test. The antifungal activity of PR10 was assessed using radial diffusion, disc diffusion and spore germination. The hemolytic assay was performed to investigate the biosafety of recombinant PR10.

Results: Recombinant maize PR10 exerted broad spectrum antifungal activity against Botrytis cinerea, Sclerotinia sclerotiorum, Fusarium oxysporum, Verticillium dahlia and Alternaria solani. Hemolysis biosafety test indicated that the protein is not poisonous to mammalian cells.

Conclusions: Maize PR10 has the potential to be used as the antifungal agent against different fungal phytopathogens. Therefore, this protein can be used in order to produce antifungal agents and fungi resistance transgenic plants.

Keywords: Pathogenesis related proteins; PR10; Antifungal activity; Bioassay; Zea mays.

\section{Background}

Since plants do not have a circulating adaptive immune system, almost always they initiate a complicated network of defense mechanism during pathogen invasion (1). Pathogenesis related proteins (PR) are an example of the best-studied plant defense proteins overexpressed in response to pathogen attacks and systemic acquired resistance (SAR) mechanism $(2,3)$. PR proteins have been recognized and categorized according to their different structures and biological activities. One of the most noteworthy families among these groups is the PR10 family with more than 100 members reported so far. PR10 families are typically acidic proteins of small molecular weight (16-19 kDa) with similar three- dimensional structures, which consist of central $\beta$-sheet covered by $\alpha$-helices on both sides $(\alpha-\beta-\alpha$ sandwich structure) that cause a compact, bipartite molecular core fixed by hydrophobic interactions and multiple hydrogen bonds. The PRs insensitivity to proteases and their high stability might be due to the compact structure (4-6). Apart from antimicrobial activity, which was detected in the majority of PR families, PR10 proteins are possibly involved in a variety of biological functions including nuclease and some other enzymatic activities in plant secondary metabolisms and plant protection against abiotic stresses (4). In addition, it has been demonstrated that some PR10 proteins control plant growth and development by modulating the endogenous cytokinin level $(1,7)$. 
Fungal diseases are counted either as the most important or the second important factor contributing to the yield losses in many substantial crops (8). PR10 family is known as efficient antifungal proteins. It has been reported that ZmPR10 and ZmPR10.1 are two homologues in maize, which are induced by most abiotic stresses such as salicylic acid, $\mathrm{CuCl}_{2}, \mathrm{H}_{2} \mathrm{O}_{2}$, cold, etiolation, wounding, and biotic stresses such as Aspergillus flavus, Erwinia stewartii and Pseudomonas syringae pv. tomato DC3000 infection (1).

\section{Objectives}

The current study deals with the recombinant expression of Zea mays PR10 in E. coli, with the goal to investigate its novel antifungal activity against some of the fungal phytopathogens. We report the successful prokaryotic expression, solubilization, refolding, purification and antifungal effects of functionally active PR10 from Zea mays (TN-05-147).

\section{Materials and Methods}

\subsection{Genomic DNA and RNA Isolation}

In order to make a comparison between genomic and cDNA of PR10, genomic DNA was extracted from the leaves of Zea mays with commercial source (TN05-147), using CTAB as described by Dan et al. (9). According to Xie et al., PR10 expression was induced by $300 \mathrm{mM} \mathrm{NaCl}$ for $30 \mathrm{~min}$ (1). Total RNA was isolated from Z. mays (TN-05-147) leaves by RNAX-plus kit (Cinagen, Iran) based on the procedure described by manufacturer. The quality of RNA and genomic DNA samples were assessed by agarose gel electrophoresis. The first strand of cDNA was synthesized with specific reverse primer and RevertAid ${ }^{\mathrm{TM}} \mathrm{M}-\mathrm{MuLV}$ reverse transcriptase based on the method described by manufacturer (Fermantas, Germany). The RNA was denatured at $70^{\circ} \mathrm{C}$, cooled slowly at $22^{\circ} \mathrm{C}$ for $2 \mathrm{~min}$ and incubated at $42^{\circ} \mathrm{C}$ for $1 \mathrm{~h}$ and at $70^{\circ} \mathrm{C}$ for $5 \mathrm{~min}$.

\subsection{PCR Amplification}

Z. mays PR10 cDNA and genomic DNA (GenBank:
FJ897503.1) were amplified using two primer pairs (PR10.1-bpF2, PR10.1-XhR for cDNA and PR10.1XaF, PR10.1-SaR for genomic DNA; Table 1). The amplicons were gel purified via High pure PCR product purification kit (Roche, Germany).

Both amplicons, cDNA and genomic DNA for PR10, were cloned inpTZ57 R/T (CinnaGen, Iran) to yield pTZNZ1 and pJNZ1, respectively.

\subsection{Sequencing and Computer Analysis}

Z. mays PR10 sequences were retrieved from GenBank and along with the sequences obtained in this study used for multiple sequence alignment. Deduced amino acid sequence from PR10 was received by EditSeq at DNASTAR and used for alignment by CLUSTALW with MegAlign at DNASTAR (Madison, WI, USA).

\subsection{Expression in E. coli}

The PR 10 cDNA sequence was cloned into the NcoI and XhoI restricted sites of pET26b (+) expression vector (Novagen, Germany) to create pETNZ1. pETNZ1 was transformed into E. coli strain Rosetta DE3.

Transformed bacterial cell was grown at $37^{\circ} \mathrm{C}$ in in $2 \times$ TY medium (16 g.L $\mathrm{L}^{-1}$ bacto-tryptone, 10 g.L.- ${ }^{-1}$ yeast extract and 5 g.L. $\left.\mathrm{L}^{-1} \mathrm{NaCl}\right)$. The medium contained 50 $\mu \mathrm{g} . \mathrm{mL}^{-1}$ kanamycin and $1 \%(\mathrm{w} / \mathrm{v})$ glucose. At $\mathrm{OD}_{600} 0.8$, cells were washed twice to remove glucose and different amounts of isopropyl- $\beta$-D-thiogalactopyranoside (IPTG) were added to induce the expression of the recombinant protein. At the same time other treatments including different incubation time and temperatures were considered for expression optimization. Protein expression was monitored using $12 \%$ sodium dodecyl sulfate-polyacrylamide gel electrophoresis (SDSPAGE) according to Laemmli (10). The amount of overexpressed PR10 in each fraction was quantified with a Bio-Rad GS-800 gel densitometer.

To optimize the efficiency of expression, orthogonal arrays of Taguchi was used. The symbolic identification of these arrays shows the main information on the size of experiment, e.g. M16 has 16 trials. Each column includes a number of conditions depending on the level

Table 1. Specific primer names, sequences and 5 ' cloning sites.

\begin{tabular}{ccc}
\hline Primer & Sequence & $\mathbf{5}^{\prime}$ cloning site \\
\hline PR10.1-XaF & GCTCTAGAATGGCCTCCACCAACAGC & Xba I \\
PR10.1-SaR & CGAGCTCTAGTTGTAGGCTTCCGG & Sac I \\
PR10.1-bpF2 & GGAAGACAACATGGCCTCCACCAACAG & Bpi I \\
PR10.1-XhR & GCTCGAGGTTGTAGGCTTCCGGGTTG & Xho I \\
\hline
\end{tabular}


Table 2. Variable factors and their levels employed in Taguchi method.

\begin{tabular}{ccccc}
\hline Factors & Level 1 & Level 2 & Level 3 & Level 4 \\
\hline IPTG $(\mathrm{mM})$ & 0.2 & 0.5 & 0.7 & 1 \\
Time $(\mathrm{h})$ & 2 & 4 & 6 & 16 \\
Temp $\left({ }^{\circ} \mathrm{C}\right)$ & 23 & 28 & 33 & 37 \\
\hline
\end{tabular}

assigned to each factor. In this study all three columns were allocated with different factors, each of which with four levels (Table 2).

Qualitik-4 software (Bloomfield Hills, MI, USA) for automatic design and analysis of Taguchi experiment was used to determine the optimum recombinant protein expression conditions.

\subsection{Western Bloting}

For immuno-detection of the expressed PR10, total protein extraction was electrophoresed on SDS-PAGE, followed by electrotransfer to PVDF (polyvinylidene fluoride) membrane. The immunoblots were developed with antibody against His-tag, based on the manufacturer's instruction (Roche, USA). The antiHis tag antibody has been conjugated to horseradish peroxidase (HRP). 4-Chloro-1-naphthol was used as a substrate for HRP results in a colored precipitate.

\subsection{Protein Extraction and Purification}

For total protein extraction, after two freeze-thaw cycles, cells were resuspended in $1 \mathrm{ml}$ lysis buffer for each 10 $\mathrm{ml}$ cell culture $\left(50 \mathrm{mM} \mathrm{NaH}_{2} \mathrm{PO}_{4}, 300 \mathrm{mM} \mathrm{NaCl}, 1 \mathrm{mM}\right.$ PMSF, pH 8) and homogenized by sonifier using $3 \mathrm{~mm}$ diameter probe with 210 um amplitude capacity and $70 \%$ vibration amplitude. The sonication procedure was performed in 6 cycles for $30 \mathrm{sec}$ with $45 \mathrm{sec}$ intervals. The mixture was centrifuged at $13,000 \times g$ for $30 \mathrm{~min}$ at $4^{\circ} \mathrm{C}$. The pellet containing the inclusion bodies was washed in three volumes of PBS and centrifuged as above. All steps were performed at $4^{\circ} \mathrm{C}$. Based on modified HaukeLilie, et al. (11), inclusion bodies, containing the overexpressed PR10, were recovered and resuspended in $100 \mathrm{mM} \mathrm{NaH}_{2} \mathrm{PO}_{4}, 10 \mathrm{mM}$ Tris- $\mathrm{HCl}$ $(\mathrm{pH} 8.0)$ containing $8 \mathrm{M}$ urea and incubated at $22^{\circ} \mathrm{C}$ for $1 \mathrm{~h}$. Urea-soluble proteins were separated from the urea-insoluble fraction by centrifugation $(13,000 \times g, 30$ $\mathrm{min}$ ) and consumed to refold into the active form. The purity of the protein was assessed by SDS-PAGE.

Renaturation of the protein was performed by dilution in the equal amount of renaturation buffer in $4^{\circ} \mathrm{C}(100$ mMTris $\mathrm{pH}$ 8.5, $100 \mathrm{mM} \mathrm{NaCl}, 100 \mathrm{mM}$ glycine, $2.5 \%$ (v/v) glycerol and $140 \mathrm{mM}$ mercaptoethanol). The urea was completely removed by gradual dialysis against buffer containing $100 \mathrm{mM}$ Tris $\mathrm{pH} 8.5$ and $100 \mathrm{mM} \mathrm{NaCl}$.

For recombinant protein purification, the renatured protein containing PR10 with $6 \times$-His-tag at its C-terminus was loaded on the Ni-NTA affinity column according to manufacturer's instruction. The recombinant PR10 concentration was estimated by Bradford method (12).

\subsection{DNA Degradation}

To evaluate the PR10 DNase activity of the refolded recombinant protein DNA degradation assays was carried out according to Xie et al. 2010 using $40 \mu \mathrm{g}$ of the purified recombinant proteins of PR10 as the sample and the protein free buffer as the negative control (1).

\subsection{Antifungal Assay}

For detection of PR10 antifungal activity, 3 different fungal growth inhibitory assays, i.e., radial diffusion, disk diffusion, and spore germination, were used. The obtained results were analyzed with t-test. The tested concentrations of the recombinant protein were 20,30 and $40 \mu \mathrm{g}$, respectively. Elution buffer was consumed as the negative control.

In radial diffusion assay, the area of growth inhibition for antifungal activity based on modified method of Broglie et al. (13) was checked using $100 \times 15 \mathrm{~mm}$ petri plates containing $25 \mathrm{~mL}$ of potato dextrose agar (PDA). After the mycelia colony had expanded, $5 \mathrm{~mm}$ holes were made at a distance of 2-5 $\mathrm{mm}$ away from the rim of the mycelial colony. Different concentrations of purified PR10 protein were added. The plates were incubated at $28^{\circ} \mathrm{C}$ until mycelia growth has enveloped peripheral hole containing the negative control (protein free buffer) and had produced crescents of inhibition around the holes containing PR10 protein. The fungal species were B. cinerea, S. sclerotiorum, F. oxysporum, V. dahliaand, A. solani.

In disc diffusion assay, the effect of PR10 against B. cinerea, F. oxysporum, V. dahlia and A. solani, was investigated. The assay was carried out according to the modified method of Nweze et al. (14). Sterilized paper discs were placed on the PDA plate. An aliquot of the mixture of purified PR10 with different concentrations and $2 \times 10^{4}$ cells. $\mathrm{mL}^{-1}$ spore suspension of $B$. cinerea, F. oxysporum, V. dahlia and A. Solani were added to each disc. Plates were incubated at $28^{\circ} \mathrm{C}$ until spore germination and mycelia growth in negative control discs were observed. Protein free buffer was used as the negative control.

In spore germination assay, the germination inhibition 
A

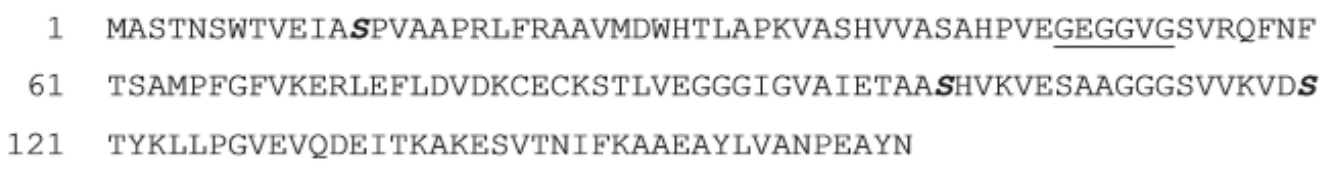

B

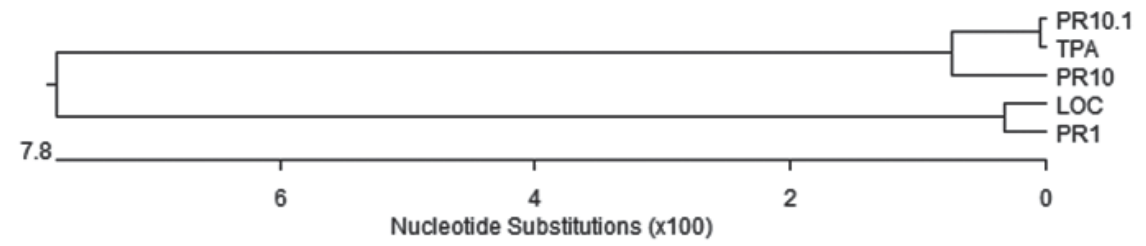

Figure 1. Amino acid sequence of PR10 cDNA. The P-loop motif is underlined and the putative phosphorylation sites are marked in bold italics (A). Phylogenetic tree obtained using CLUSTALW by MegAlign at DNASTAR for comparing the PR10 amino acid sequence with TPA (DAA44938.1), ZmPR10.1 (ADA68331.1), LOC100192117 (NP_001131012.1) and PR1 (ACG29538.1)(B).

effect of PR10 against B. cinerea, S. sclerotiorum, F. oxysporum, $V$. dahlia and $A$. solani was investigated based on Xu Hu et al. 1997 using $15 \mu \mathrm{g}$ of PR10 as the sample and protein free buffer as the negative control (15).

\subsection{Hemolytic Assay}

Since there are several reports of antimicrobial peptides showing cytotoxic activity against eukaryotic cells, recombinant PR10 was also assayed for hemolytic activity against human erythrocytes. Hemolytic activity of PR10 was assessed based on Park et al. (16). Human red blood cells in PBS $\left(\mathrm{A}_{\text {blank }}\right)$ and in $0.1 \%(\mathrm{v} / \mathrm{v})$ Triton $\mathrm{X}-100\left(\mathrm{~A}_{\text {triton }}\right)$ were used for the negative and positive controls, respectively. Also, the hemolytic activity of protein free buffer was measured and compared with PR10 hemolytic activity. The obtained results were analyzed with t-test. The percent hemolysis was calculated according to the equation:

Hemolysis $\%=\left[\left(\mathrm{A}_{\text {sampel }}-\mathrm{A}_{\text {blank }}\right) /\left(\mathrm{A}_{\text {triton }}-\mathrm{A}_{\text {blank }}\right)\right] \times 100$

\section{Results}

\subsection{PR10cDNA Cloning and Sequence Analysis}

The 498 bp and 574 bp PCR products were amplified from cDNA and genomic DNA of Z. mays (TN-05147) leaf using specific primers as stated above. The amplicons were cloned in cloning vector.

Comparison between the cloned cDNA and genomic DNA indicated that PR10 contains one 77-bp intron and two exons of $483 \mathrm{bp}$ in total, encoding a peptide of 160 amino acids with $\sim 16854.13 \mathrm{Da}$. A typical GXGGXG motif was evident at amino acid residues 48-53 (Fig.1A, underlined) of PR10, known as the "P-loop" (phosphate-binding loop), which was reported to be frequently seen in protein kinases and nucleotidebinding proteins (17).

Multiple sequence alignment of the deduced amino acid with related proteins, TPA (DAA44938.1), ZmPR10.1 (ADA68331.1), LOC100192117 and PR1 (ACG29538.1) was performed using CLUSTALW. Alignment showed very high sequence homology (more than 87\%; Fig. 1B). Signal peptide was absent in all proteins.

\subsection{Prokaryotic Expression}

The cDNA of PR10 was isolated from pTNZ1 by enzymatic digestion utilizing Bpi I and Xho I, and sub cloned in pET26 b(+) prokaryotic expression vectorwith an inbuilt $\mathrm{His}_{6}-$ tag. The recombinant protein was overexpressed in E. coli Rosetta (DE3), which supplies tRNA genes for rare codons. In order to optimize the recombinant protein expression, M16 orthogonal experimental design was used to examine the effect of induction time and temperature, and IPTG concentration. The experiments were managed using four levels for each factor.

The 17.9 $\mathrm{kDa}$ protein band was observed on SDSPAGE and the amount of expressed protein was estimated via densitometry using Qualitek-4 software (Fig. 2). The influence of each factor on the recombinant protein expression was shown in Table 3A. When the interactions of different factors were calculated (Table 
Table 3. Qualitek-4 analysis: A) Main factors (average effects of factor and interactions). B) Estimation of severity index for different factors.

\begin{tabular}{|c|c|c|c|c|c|c|}
\hline \multicolumn{7}{|l|}{ A) } \\
\hline Factor & Level 1 & Level 2 & Level 3 & Level 4 & & \\
\hline IPTG (mM) & -1.69 & 1.075 & 0.84 & 1.712 & & \\
\hline Time (h) & -1.139 & 0.954 & 0.884 & 1.238 & & \\
\hline Temp $\left({ }^{\circ} \mathrm{C}\right)$ & -0.071 & 0.106 & 0.225 & 1.677 & & \\
\hline \multicolumn{7}{|l|}{ В) } \\
\hline Interaction & \multicolumn{2}{|l|}{ Factor Pairs } & \multicolumn{2}{|l|}{ Columns* } & SI $(\%) * *$ Col. & Opt.*** \\
\hline Temp $\times$ Time & \multicolumn{2}{|l|}{$2 \times 3$} & \multicolumn{2}{|l|}{48.39} & 1 & {$[2,4]$} \\
\hline IPTG $\times$ Temp & \multicolumn{2}{|l|}{ ). $1 \times 2$} & \multicolumn{2}{|l|}{1.22} & 3 & {$[3,2]$} \\
\hline IPTG × Time & \multicolumn{2}{|l|}{$1 \times 3$} & \multicolumn{2}{|l|}{0.73} & 2 & {$[3,4]$} \\
\hline
\end{tabular}

3B), induction time and temperature exhibited the highest interaction severity index (SI) with 48.39\%. The optimum conditions for protein expression were 16 $\mathrm{h}$ of induction with $1 \mathrm{mM} \mathrm{IPTG}$ at $37^{\circ} \mathrm{C}$.

The expression of protein was confirmed by western blot (Fig. 3A). The majority of recombinant PR10 was not soluble in water or low salt buffers and expressed as inclusion body (Fig. 3B). E. coli cells transformed with an empty vector was considered as negative control (Fig. 3A, B).

The inclusion bodies were denatured in the presence of $8 \mathrm{M}$ urea and refolded by removing urea gradually through dialysis. The refolded recombinant PR10 was purified using Ni-NTA affinity chromatography column (Fig. 3C). The activity of purified refolded PR10 was confirmed by its clear DNase activity against the maize genomic DNA. The protein free buffer was used as negative control (Fig. 3D).

\subsection{Antifungal and Hemolytic Assays}

The antifungal activity of the refolded purified PR10 was investigated using numbers of assays. The purified PR10 protein showed an inhibitory effect on conidia germination and hyphal growth of B. cinerea, S. sclerotiorum, F. oxysporum, V. dahlia and $A$. solani. The conidia germination and hyphal growth in radial and disc diffusion assays were decreased by increasing the concentration of purified PR10 (Figs. 4 and 5). Furthermore, the fungi tested in spore germination assay appeared to be sensitive to $15 \mu \mathrm{g}$ of PR10.

These results demonstrated the inhibition effect of recombinant PR10 on the growth of tested fungi in a concentration dependent manner.

No significant hemolytic activity $(<0.5 \%)$ at a concentration of up to $60 \mu \mathrm{g}$ of recombinant PR10 was observed.

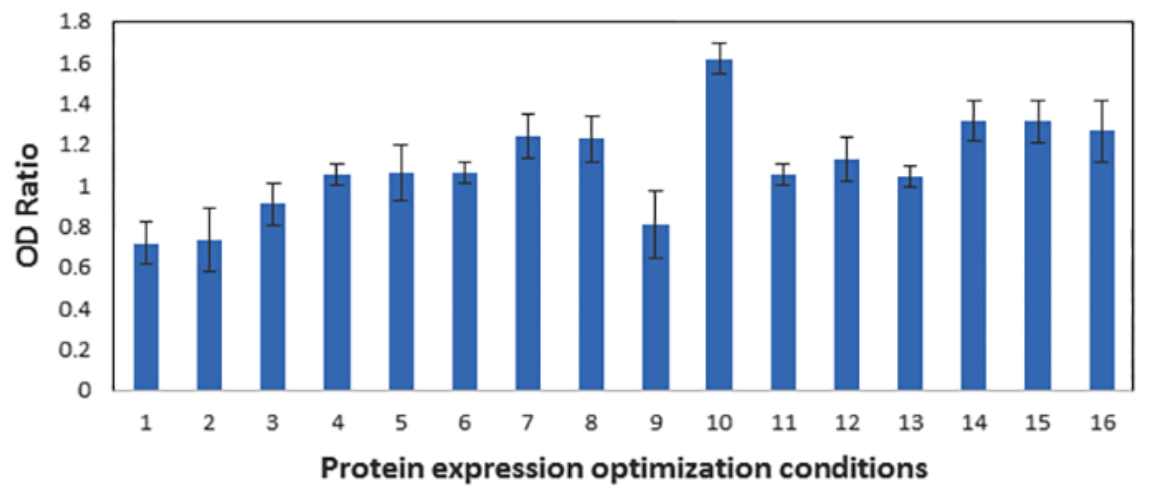

Figure 2. Quantitative analysis of protein expression optimization conditions. 1-16: Different trials used in M16 orthogonal experimental design. 


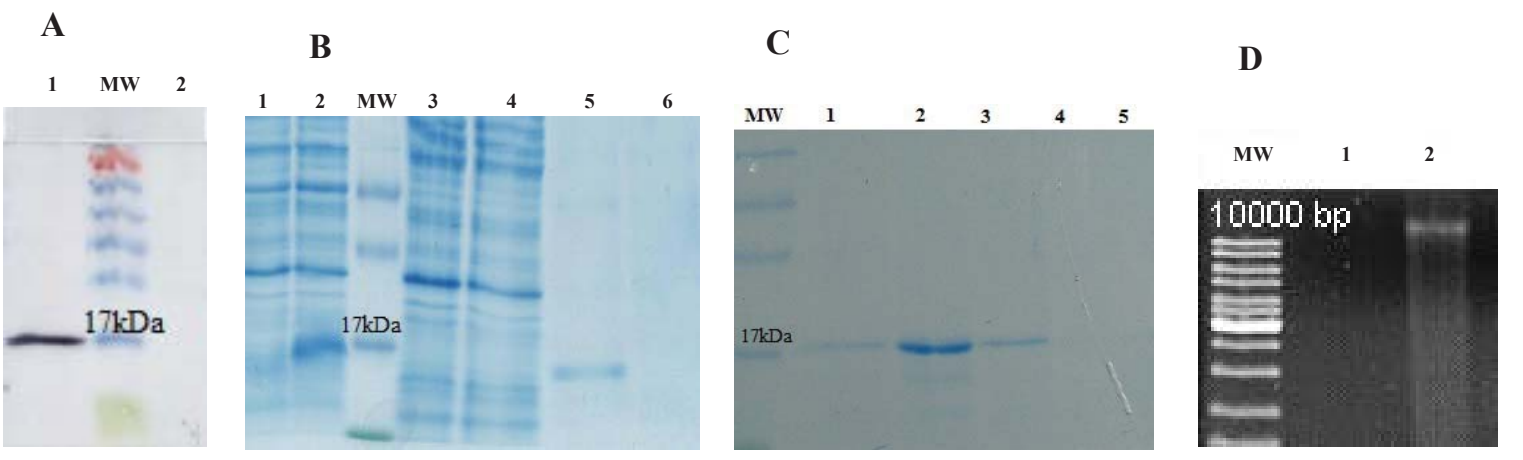

Figure 3. (A) Western blotting. 1: Recombinant PR10. 2: Negative control (extract protein from E. coli cells transformed with empty vector). (B) Protein localization. 1, 4 and 6: Negative controls (extract protein from E. coli cells transformed with empty vector). 2, 3 and 5: Protein expression of E. coli carrying pETNZ1. 1, 2: Total protein. 3, 4: soluble proteins. 5, 6: insoluble proteins (inclusion bodies). (C) Purified recombinant PR10. 1: MES, 2, 3: elution, 4: wash, 5: flow through. (D) DNA degradation test. 1:DNA treated with recombinant PR10. 2: Negative control (protein free buffer). A, B, C and D MW: molecular marker (Thermo Scientific, SM0671, Germany)

A

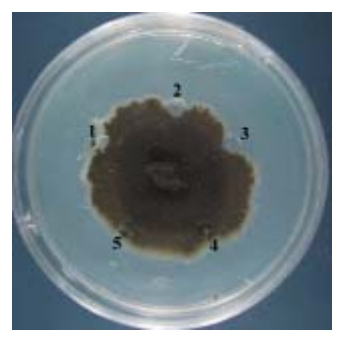

B

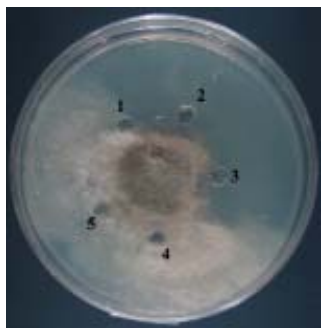

C

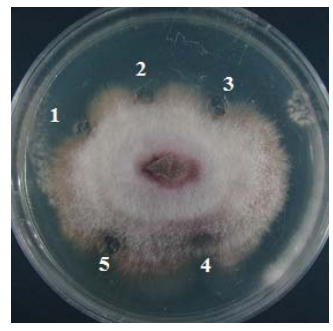

D

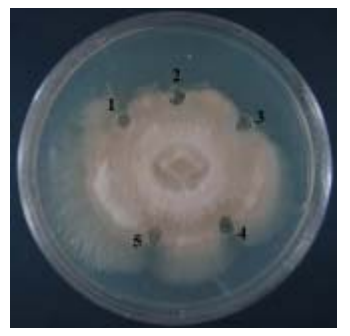

$\mathbf{E}$

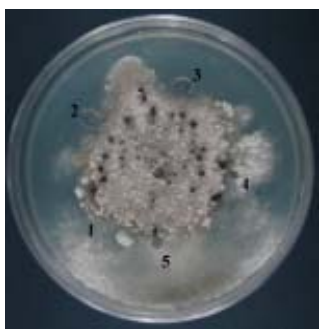

Figure 4. Radial diffusion assay. (A) A. solani, (B) B. cinerea, (C) V. dahlia, (D) F. oxysporum, (E) S. sclerotiorum. 1-3: Treated with 20, 30 and $40 \mu \mathrm{g}$ of recombinant PR10, 4 and 5: PR10 free buffer as the negative control.

\section{Discussion}

PR10 family is an important member of pathogenesis related proteins, which has a significant role in plant defense mechanism against a variety of biotic and abiotic stress. For instance, some of tobacco PRs were recognized as chitinases and $\beta$-1,3-glucanases with potential of antifungal activity (18-20). Thus, we have examined in vitro antifungal activity of recombinant PR10.

PR10 cDNA and gene were isolated from $Z$. mays (TN-05-147) leaf. The comparison between cDNA and genomic DNA sequences of PR10, showed the existence of $77 \mathrm{bp}$ intron, which is similar to ZmPR10.1 (1). The comparison of deduced amino acid sequence of PR10 and the related amino acid sequences indicated a high degree of homology. According to phylogenic tree (Fig. 1-B), the ancestor of PR10 and ZmPR10.1 and TPA was the same. Furthermore, the same residues for potential phosphorylation sites in all related amino acids were evident demonstrating a probable structural and functional similarity $(1,21)$. In addition, similar to the other members of PR10 family, the lack of signal 
A

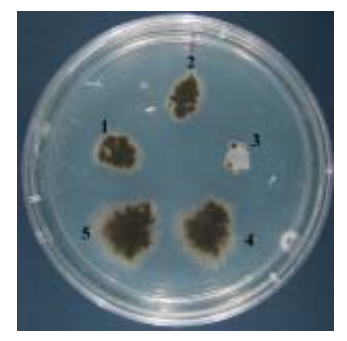

B

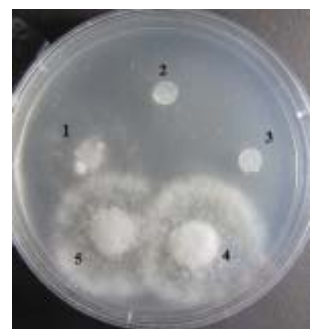

C

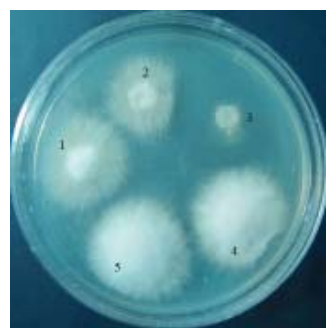

D

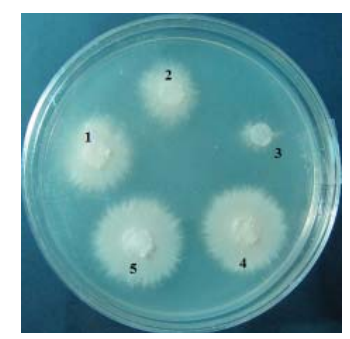

Figure 5. Disc diffusion assay. (A) A. solani, (B) B. cinerea, (C) V. dahlia, (D): F. oxysporum. 1-3: Treated with 20, 30 and $40 \mu \mathrm{g}$ of recombinant PR10.

peptide indicated their intracellular localization (1).

It is perceived that recombinant proteins overexpression in bacteria usually lead to form insoluble proteins containing most of the expressed protein (3). Although the expressed ZmPR10.1 was soluble, ZmPR10 and the recombinant PR10 obtained in this study were formed into insoluble inclusion bodies (1, 21). It is assumed that the lack of post translational modification in bacteria (phosphorylation) may cause such result (22). Recombinant PR10 solubilized inclusion bodies were successfully renatured by slow dialysis that followed by affinity column purification that resulted in a functionally active PR10. The activity of refolded purified PR10 was confirmed by the maize genomic DNA degradation. The same result about the effect of ZmPR10.1 on the maize genomic DNA was reported by Xie et al. (1).

Both recombinants, ZmPR10 and ZmPR10.1, exhibited antifungal activity against $A$. flavus $(1,21)$. In addition, ZmPR10 inhibits the growth of V. dahlia (21). The comparison of conidia germination and fungal growth in the presence of various concentrations of recombinant purified PR10 revealed that it has the potential to inhibit conidial germination and hyphal growth of A. solani, B. cinerea, V. dahlia, F. oxysporum, S. sclerotiorum. Although the recombinant PR10 concentration for fungal growth inhibition was varied, $40 \mu \mathrm{g}$ of this protein was enough to make inhibitory zone for all tested fungi. The antifungal effect of PR10 proteins is probably due to inhibition of hyphal growth, spore lysis and/or reduction in spore germination or viability of germinated spores. However, the mechanism by which PR10 proteins bring about these effects has not been completely understood $(1,7,21)(1,16)$.

Considering antifungal activity of $Z$. mays PR10 against broad spectrum of phytopathogenic fungi, this protein can be used to develop fungal resistant crop plants.
So the results presented here will be useful to achieve this aim. So hemo-compatibility of PR10 protein should be considered since it might be applied by human in antifungal drugs or transgenic plants. The hemo-compatibility of PR10 was demonstrated as it showed no hemolytic activity.

\section{Acknowledgments}

This research was supported by National Institute of Genetic Engineering and Biotechnology (NIGEB).

\section{References}

1. Xie YR, Chen ZY, Brown RL, Bhatnagar D. Expression and functional characterization of two pathogenesis-related protein 10 genes from Zea mays. J Plant Physiol. 2010 Jan 15;167(2):121-30. PubMed PMID: 19682768. Epub 2009/08/18. eng. http://dx.doi.org/10.1016/j.jplph.2009.07.004.

2. Chen JC, Lu HC, Chen CE, Hsu HF, Chen HH, Yeh HH. The NPR1 ortholog PhaNPR1 is required for the induction of PhaPR1 in Phalaenopsis aphrodite. Bot Stud. 2013;54(1):1-11. DOI: 10.1186/1999-3110-54-31.

3. Kirubakaran SI, Sakthivel N. Cloning and overexpression of antifungal barley chitinase gene in Escherichia coli. Protein Expres Purif. 2007 Mar;52(1):159-66. PubMed PMID: 17029984. DOI: 10.1016/j.pep.2006.08.012.

4. Liu J-J, Ekramoddoullah AK. The family 10 of plant pathogenesis-related proteins: their structure, regulation, and function in response to biotic and abiotic stresses. Physiol Mol Plant P. 2006;68(1):3-13. DOI: 10.1016/j.pmpp.2006.06.004.

5. Edreva A. Pathogenesis-related proteins: research progress in the last 15 years. Gen Appl Plant Physiol. 2005;31(1-2):105-24.

6. Ziadi Sl, Poupard P, Brisset M-n, Paulin J-P, Simoneau P. Characterization in apple leaves of two subclasses of PR-10 transcripts inducible by acibenzolar-S-methyl, a functional analogue of salicylic acid. Physiol Mol Plant P. 2001;59(1):3343. http://dx.doi.org/10.1006/pmpp.2001.0343.

7. Jomová K, Feszterová M, Morovič M. Expression of pathogenesis-related protein genes and changes of superoxide dismutase activity induced by toxic elements in Lupinus luteus L. JMBFS. 2011; 1(3) 437-44.

8. Wang Y, Kausch AP, Chandlee JM, Luo H, Ruemmele BA, Browning M, Jackson N, Goldsmith M R. Co-transfer and 
expression of chitinase, glucanase, and bar genes in creeping bentgrass for conferring fungal disease resistance. Plant Sci. 2003;165(3):497-506. DOI: 10.1016/s0168-9452(03)00198-5.

9. Dan S, Marton I, Dekel M, Bravdo B-A, He S, Withers SG, Shoseyov O. Cloning, expression, characterization, and nucleophile identification of family 3, Aspergillus niger $\beta$-glucosidase. J Biol Chem. 2000;275(7):4973-80. DOI: org/10.1074/jbc.275.7.4973.

10. Laemmli UK. Cleavage of structural proteins during the assembly of the head of bacteriophage T4. Nature. 1970;227(5259):6805. DOI: $10.1038 / 227680 \mathrm{a} 0$.

11. Hauke Lilie ESaRR. Advances in refolding of proteins produced in E. coli. Curr Opin Biotech. 1998;9(5):497-501. DOI: 10.1016/s0958-1669(98)80035-9.

12. Bradford MM. A rapid and sensitive method for the quantitation of microgram quantities of protein utilizing the principle of protein-dye binding. Anal Biochem. 1976;72(1):248-54. DOI: 10.1016/0003-2697(76)90527-3.

13. Brogue K, Chet I, Holliday M, Cressman R, Biddle P, Knowlton S, MAUVAIS C J, Broglie R. Transgenic plants with enhanced resistance to the fungal pathogen Rhizoctonia solani. Science. 1991;254(5035):1194-7. DOI: 10.1126/science.254.5035.1194.

14. Nweze EI, Mukherjee PK, Ghannoum MA. Agar-based disk diffusion assay for susceptibility testing of dermatophytes. $J$ Clinical Microbiol 2010 Oct;48(10):3750-2. PubMed PMID: 20668120. J Clin Microbiol. 2010;48(10):3750-2. DOI: 10.1128/jcm.01357-10.

15. Hu X, Reddy A. Cloning and expression of a PR5-like protein from Arabidopsis: inhibition of fungal growth by bacterially expressed protein. Plant Mol Biol. 1997;34(6):949-59.
16. Park SC, Lee JR, Shin SO, Park Y, Lee SY, Hahm KS. Characterization of a heat-stable protein with antimicrobial activity from Arabidopsis thaliana. Biochem Bioph Res. Commun. 2007;362(3):562-7. DOI: 10.1016/j.bbrc.2007.07.188.

17. Saraste M, Sibbald PR, Wittinghofer A. The P-loop-a common motif in ATP- and GTP-binding proteins. Trends Biochem Sci. 1990 Nov;15(11):430-4. PubMed PMID: 2126155. Epub 1990/11/01. eng. DOI: 10.1016/0968-0004(90)90281-f.

18. Van Loon L, Van Strien E. The families of pathogenesis-related proteins, their activities, and comparative analysis of PR-1 type proteins. Physiol Mol Plant P. 1999;55(2):85-97. DOI: 10.1006/ pmpp.1999.0213.

19. Takahashi M, Shigeto J, Izumi S, Yoshizato K, Morikawa H. Nitration is exclusive to defense-related PR-1, PR-3 and PR-5 proteins in tobacco leaves. Plant Signal Behav. 2016;11(7):e1197464. DOI: 10.1080/15592324.2016.1197464.

20. Ebrahim S, Usha K, Singh B. Pathogenesis-related (PR)proteins: Chitinase and $\beta-1,3$-glucanase in defense mechanism against malformation in mango (Mangifera indica L.). Sci Hortic. 2011;130(4):847-52. DOI: 10.1016/j.scienta.2011.09.014.

21. Chen ZY, Brown RL, Rajasekaran K, Damann KE, Cleveland TE. Identification of a Maize Kernel Pathogenesis-Related Protein and Evidence for Its Involvement in Resistance to Aspergillus flavus Infection and Aflatoxin Production. Phytopathology. 2006 Jan;96(1):87-95. PubMed PMID: 18944208. Epub 2008/10/24. eng. DOI: 10.1094/phyto-96-0087.

22. Baneyx F, Mujacic M. Recombinant protein folding and misfolding in Escherichia coli. Nature Biotechnol. 2004;22(11):1399-408. DOI: 10.1038/nbt1029. 